\title{
ANALISIS HUBUNGAN ARUS BOCOR DAN PENYEBABNYA TERHADAP KERUGIAN PEMBAYARAN REKENING BULANAN KONSUMEN INSTALASI RUMAH TANGGA PADA PT.PLN CABANG SORONG
}

\author{
Irman Amri \\ Fakultas Teknik Universitas Al-Amin Muhammadiyah Sorong
}

\begin{abstract}
Abstrak
Kondisi dimana jumlah pembayaran beban rekening listrik sering dinilai kurang masuk akal oleh konsumen karena nilainya berbeda dengan perhitungan pemakaian dan beban terpasang pada rumah konsumen diperkirakan salah satunya disebabkan oleh adanya arus bocor. Hasil penelitian dilakukan di kelurahan malawei Kota Sorong terhadap 50 sampel menunjukkan bahwa umur instalasi akan mempengaruhi besarnya arus bocor sebesar 26,7\% untuk Daya 900 VA sentara 1300 VA sebesar 32,6\% sementara pengaruh daya terpasang tidak cukup besar walaupun dari analisis korelasi menunjukkan pengaruh positif sekalipun kecil dengan hubungan sebesar .0,254.

Hasil penelitian juga menunjukkan bahwa pengaruh arus bocor akan memberikan nilai penambahan pembayaran listrik rata rata Rp. 2.161.- untuk daya terpasang 900 VA sedangkan untuk daya 1300 VA sebesar Rp. 3.076,-. Sementara jumlah penambahan biaya maksimum untuk daya 1300 sebesar Rp. 5.773. sedangkan Daya 900 VA sebesar Rp. 4.326. sedangkan faktor lain yang memungkinkan untuk mempengaruhi besar arus bocor adalah panjang saluran. Kata kunci : arus bocor,beban, rekening listrik
\end{abstract}

\section{PENDAHUPENDAHULUAN}

Saat ini sering dijumpai kondisi dimana jumlah pembayaran beban rekening listrik sering dinilai kurang masuk akal oleh konsumen karena nilainya berbeda dengan perhitungan pemakaian dan beban terpasang pada rumah konsumen yang bersangkutan. Secara realistis seharusnya perbedaan antara nilai anggapan konsumen dengan nilai yang tercatat oleh petugas pencatat PLN yang kemudian menjadi nilai yang tertagihkan adalah sama antara pemilik dengan pihak PLN. Perbedaan tersebut memang bisa terjadi karena faktor non teknis dimana pencatatan petugas PLN cenderung asal asalan, namun demikian tidak menutup kemungkinan bahwa perbedaan antara anggapan pemilik dan pencatatan petugas PLN sebenarnya terjadi karena adanya faktor teknis yang selama ini kurang disadari.

Kondisi ideal suatu instalasi listrik rumah tangga, yaitu ketika semua beban tidak tersambung maka tidak ada arus yang mengalir melalui penghantar karena kawat fasa dan kawat netral maupun pentanahan dipisahkan oleh isolator. Hal ini tentu seharusnya menyebabkan tidak ada perubahan pada meteran milik konsumen tersebut

Kenyataan yang terjadi, dalam isolator tersebut masih terdapat sedikit elektron bebas yang dapat mengalirkan arus (Naidu, 1995). Selain itu energi listrik yang disalurkan ke konsumen biasanya akan menyebabkan adanya arus lain yang juga mengkonsumsi energi tersebut sehingga besar arus yang mengalir menjadi lebih besar dari arus wajarnya karena beberapa hal seperti kapasitansi antar penghantar dan perubahan kekuatan isolasi yang kesemuanya menyebabkan arus bocor. Jika menggunakan arus bolak-balik dengan frekuensi $50 \mathrm{~Hz}$, yang menyebabkan arus bocor melalui kapasitas isolasi lebih besar daripada arus bocor kalau digunakan arus searah (DC).

Kebijakan pemerintah yang semakin mengurangi subsidi disebagian besar aspek (Radar Sorong, 10 Januari 2007) yang disertai dengan daya mampu mesyarakat secara umum semakin menurun disebabkan oleh kondisi ekonomi yang tidak stabil sejak krisis ekonomi tahun 1997 (Kompas, Januari 2000) menyebabkan harga listrik yang naik dalam hitungan yang cukup murah terasa menjadi sangat tinggi oleh 
masyarakat pemakai. Karena itu perlu diteliti lebih jauh faktor lain yang menyebabkan semakin tingginya pembayaran rekening masyarakat diluar dari faktor faktor kebijakan dan kondisi ekonomi tersebut.

\section{TINJAUAN PUSTAKA}

\subsection{Arus bocor dan faktor penyebabnya}

Arus listrik adalah aliran elektron dari yang bertegangan lebih tinggi ke tegangan yang lebih rendah. Jadi, setiap ada beda tegangan ada aliran arus yang mengalir. Perbedaan tegangan dimaksud adalah adaya beda potensial antara 2 (dua) buah titik yang dihubungkan

Arus bocor adalah arus yang mengalir dalam instalasi listrik yang melalui isolasi listrik maupun akibat kapasitans saluran untuk tegangan bolak-balik serta adanya rugi-rugi konduktor (Malik, 1998).

Kehilangan daya konduktor pada arus $\mathrm{AC}$ tergantung pada arus rms dan resistans AC efektif konduktor. Resistans AC lebih besar dibanding resistans DC jarena adanya efek kulit terhadap arus AC, sehingga kehilangan daya konduktor pada arus AC lebih besar di banding pada arus DC. (Malik, 1998)

Faktor yang mempengaruhi besarnya arus bocor yang terjadi dalam instalasi listrik adalah tegangan sistem, kekuatan isolasi, dan kapasitansi saluran

\section{Kekuatan Isolasi}

Isolasi adalah sifat atau bahan yang dapat memisahkan secara elektris dua buah penghantar atau lebih yang berdekatan sehingga tidak terjadi kebocoran arus atau lompatan api (flashover). Isolasi juga dipakai untuk memisahkan dua sistem tegangan yang berbeda maupun fase yang berbeda dalam sebuah sistem tenaga listrik . Jadi fungsi utama isolasi adalah sebagai sarana pengaman. (Arismunandar, 1994).

Untuk sistem tenaga listrik untuk keperluan transmisi sampai pada distribusi dengan tegangan sampai tegangan menengah umumnya menggunakan isolator pasangan luar dengan bahan dasar yang banyak dipakai di Indonesia terbuat dari keramik, gelas, dan porselin. Sedangkan bahan isolasi yang banyak dipakai untuk kabel tegangan rendah adalah poliviniklorida (PVC). PVC tidak bisa digunakan untuk aplikasi tegangan tinggi karena mempunyai sifat dielektrik tinggi dan kehilangan daya yang tinggi pula. (Naidu,l 1995).

Kekuatan isolasi tergantung pada umur isolasi. Semakin lama sebuah isolasi dimanfaatkan maka akan semakin menurun kualitasnya. penurunan kualitas bahan isolasi secara kimiawi (deterioration) terhadap karakteristik listriknya umumnya disebabkan karena panas, kelembaban, kerusakan mekanis, tegangan lebih (Arismunandar, 1994).

\section{Kapasitas Saluran}

Salurannya yang terdiri atas dua kawat atau lebih yang di beri tegangan akan bersifat seperti kapasitor. Sifat kapasitif antara dua penghantar tersebut akan mengalirkan arus jika di beri tegangan bolak-balik. Instalasi listrik rumah tangga menggunakan tagangan bolak-balik, sehingga kapasitans saluran akan menyebabkan adanya arus bocor.

Arus bocor yang disebabkan kapasitansi saluran dapat diungkapkan dengan persamaan (Smith, 1990).

$$
\mathbf{i}=\mathbf{C} \frac{\mathrm{dv}}{\mathrm{dt}}
$$

dengan :

$$
\begin{aligned}
\mathrm{I} & =\operatorname{arus}(\mathrm{A}) \\
\mathrm{C} & =\operatorname{Kapasitas}(\mathrm{F}) \\
\frac{\mathrm{dv}}{\mathrm{dt}} & =\text { perubahan tegangan terhadap }
\end{aligned}
$$
waktu

Dari persamaan (1) terlihat bahwa arus tersebut berbanding lurus dengan nilai Kapasitansi saluran dan besar perubahan tegangan yang berlangsung terhadap waktu

\subsection{Kerugian Konsumen}

Arus bocor instalasi listrik rumah tangga merugikan konsumen, yang perbulannya dapat dihitung sebagai berikut : Biaya $/$ bulan $=($ biaya/jam $) \times 24$ jam $\times 30$ hari

$$
\begin{aligned}
\text { Biaya } / \text { jam } & =k W h \times \text { tarif } \\
\text { Wh } & =V \times \text { i } 1 \text { jam }
\end{aligned}
$$


dengan :

$$
\begin{array}{ll}
\mathrm{Wh} & =\mathrm{VA} \text { hour (VA jam) } \\
\mathrm{kWh} & =1000 \mathrm{Wh} \\
\mathrm{V} & =\text { Tegangan (Volt) } \\
\mathrm{I} & =\text { Arus (Ampere) } \\
\text { Tarif } & =\text { Tarif listrik(tergantung }
\end{array}
$$
pada TDL)

Sehingga semakin besar arus bocor yang terjadi pada instalasi rumah tangga akan menyebabkan bertambahnya biaya perjam yang harus dibayarkan konsumen.

\section{METODE PENELITIAN}

\subsection{Lokasi dan Penelitian}

Lokasi penelitian ini adalah pada wilayah Kota Sorong, Propinsi Papua Barat dengan mengambil data dari instalasi listrik rumah-rumah di lokasi Kelurahan malawei, Disrik Sorong, Kota Sorong.

\subsection{Sumber Data}

Populasi penelitian ini diambil dari lokasi Kelurahan Malawei, Distrik Sorong, Kota Sorong dan dengan jumlah KK sebagai dasar perhitungan.

Untuk populasi dengan jumlah sampel yang relatif besar, maka dilakukan penarikan dengan teknik random sampling sebesar $10 \%$ dari total populasi (Arikunto, 2003). Sehingga jumlah sampel yang akan diambil untuk Kelurahan Klademak dengan jumlah jiwa 8584 / 890 KK ( BPS Kota Sorong 2007 ) adalah $890 \times 10 \%=89$ responden

\subsection{Teknik Analisis Data}

Hasil penelitian dipengaruhi oleh banyaknya sampel yang diambil. Menurut statistik, sampel yang diambil cukup representatif jika cacahnya lebih besar atau sama dengan 30 (Walpole, 1986).

Teknik pengambilan sampel adalah simple random sampling yaitu teknik sampling yang memberikan peluang yang sama bagi setiap unsur populasi untuk dipilih sebagai sampel. Pengambilan sampel dilakukan secara acak tanpa memperhatikan strata yang ada dalam populasi. Pemilihan metode ini untuk memudahkan dalam pengambilan data. (singarimbun, 1989)
Penelitian ini menggunakan dua buah variabel bebas $\left(\mathrm{X}_{1}\right)$ dan $\left(\mathrm{X}_{2}\right)$ serta suatu variabel terikat (y).

a. Variabel bebas : $X_{1}-$ umur instalasi listrik

b. Variabel bebas : $\mathrm{X}_{2}-$ arus maksimal sistem

c. Variabel terikat : y - arus bocor

Variabel umur instalais listrik $\left(\mathrm{x}_{1}\right)$ diperoleh dari hasil wawancara dengan pemilik rumah, sedangkan variabel arus maksimal sistem $\left(\mathrm{X}_{2}\right)$ dapat diketahui dari pengamatan langsung pengaman (MCB) yang terpasang. Varaibel arus bocor (y) didapat dengan mengukur langsung arus bocor yang terjadi dengan multimeter digital.

Analisi regresi linier dua peubah dilakukan untuk menguji lebih lanjut penelitian yang telah dilakukan yaitu untuk mengetahui hubungan variabel bebas dengan variabel terikat. Ikatan linier sederhana digunakan kendati model sebenarnya belum diketahui. Model yang dipakai merupakan suatu fungsi pendekatan yang diharapkan akan cukup baik mewakili fungsi sebenarnya dalam daerah yang di teliti.

Model linier yang akan di cobakan adalah model linier dalam dua peubah (Sembiring, 1995) yaitu :

$Y_{i}=A_{0}+A_{1 .} x_{1}+A_{2 .} x_{2}+\varepsilon_{i}$

Dengan :

$$
\begin{array}{ll}
\mathrm{Y} & =\text { Arus bocor } \\
\mathrm{A}_{0} & =\text { Koefisien Regresi } \\
\mathrm{A}_{1} & =\text { koefisien regresi } \mathrm{x}_{1} \\
\mathrm{~A}_{2} & =\text { Koefisien regresi } \mathrm{x}_{2} \\
\mathrm{X}_{1} & =\text { Umur Instalasi } \\
\mathrm{X}_{2} & =\text { Daya terpasang } \\
\varepsilon_{1} & =\text { error (galat) }
\end{array}
$$

Koefisien korelasi digunakan untuk mencari hubungan antar variabel. Penelitian ini bertujuan untuk melihat hubungan antara variabel-variabel independen dan variabel dependennya, antar variabel independen serta anatara variabel umur instalasi (dependen)terhadap variabel arus bocor (dependen).

Khusus untuk mengetahui kerugian konsumen akibat adanya arus bocor akan dilakukan dengan melihat nilai rekening yang harus dibayarkan oleh konsumen diperhitungkan berdasarkan selisih antara 
ISSN 1979-7540

pencatatan meteran bulan berjalan ( Bulan $\mathrm{n}$ ) di kurangi dengan pencatatan rekening terakhir bulan lalu ( bulan $\mathrm{n}-1$ ). Sedangkan nilai realistis diperhitungkan dengan melihat berapa besar beban yang terpakai secara riil oleh konsumen setiap hari selama masa penelitian dan dilakukan responden. Sehingga akan terlihat selisihnya yang kemudian diperhitungkan secara statistik apakah cukup signifikan menyebabkan kerugian pada konsumen.

\section{HASIL DAN PEMBAHASAN}

Data yang diperoleh dan digunakan adalah data yang diambil pada bulan Oktober 2008 , dengan sekali pengukuran data dan diambil pada kondisi cuaca dengan kelembaban yang sedang mengingat musim penghujan dan musim kemarau tidak tetap diwilayah papua, sehingga pengaruh arus bocor karena kondisi cuaca dengan kelembaban sedang tetap diasumsikan ada walaupun tidak sebesar pada kondisi musim hujan.

Adapun Jumlah sampel yang diabil dapat dilihat pada tabel berikut ini :

Tabel 1. Jumlah Sampel yang diambil

\begin{tabular}{|c|c|c|c|}
\hline No & Daya terpasang (Watt) & Jumlah Sampel & Persen Sampel \\
\hline 1 & 2 & 3 & 4 \\
\hline 1 & 900 & 30 & 60 \\
\hline 2 & 1300 & 20 & 40 \\
\hline & Jumlah & 50 & 100 \\
\hline
\end{tabular}

Adapun profil arus bocor dalam Instalasi listruk Rumah tangga tersebut dapat dilihat pada grafik berikut ini :

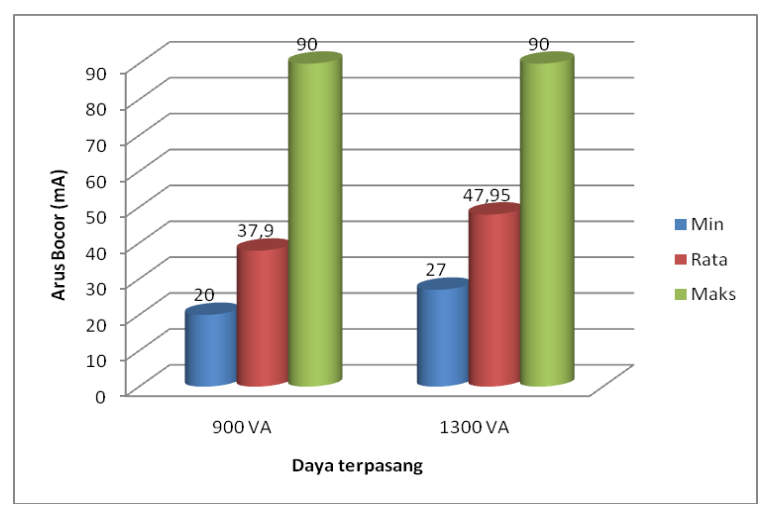

Gambar 1. Grafik Perbandingan Arus bocor dan daya terpasang

\section{A. Hubungan antara Arus Bocor dengan Umur Instalasi dan Daya Terpasang}

Model yang baik menangkap kecenderungan umum yang terdapat pada data. dalam hal demikian hubungan antara peubah dengan respon yang terdapat pada data telah terwakili dengan cukup baik pada model.(sembiring, 1995)

\section{Arus Bocor dan Umur Instalasi}

hubungan antara arus bocor dengan Umur Instalasi dapat dilihat dari hasil analisis korelasi yang dilakukan terhadap data yang diperoleh dengan mengunakan Program SPSS Ver. 13 , seperti yang terlihat pada tabel berikut ini :

Model Summary b

\begin{tabular}{|l|c|c|c|c|c|}
\hline Mode & R & R Square & $\begin{array}{c}\text { Adjusted } \\
\text { R Square }\end{array}$ & $\begin{array}{l}\text { Std. Error } \\
\text { the Estima }\end{array}$ & $\begin{array}{c}\text { Durbin- } \\
\text { Watson }\end{array}$ \\
\hline 1 &, 535 a &, 287 &, 261 & 16,432 &, 901 \\
\hline
\end{tabular}

a. Predictors: (Constant), Umur Instalasi

b.Dependent Variable: Arus bocor

Correlations

\begin{tabular}{|ll|r|r|}
\hline & & Arusbocor & UmurInstalasi \\
\hline Arusbocor & Pearson Correlation & 1 &, $535^{*}$ \\
& Sig. (2-tailed) & &, 002 \\
& $\mathrm{~N}$ & 30 & 30 \\
\hline UmurInstalasi & Pearson Correlation &, $535^{*}$ & 1 \\
& Sig. (2-tailed) &, 002 & 30 \\
\hline
\end{tabular}

**.Correlation is significant at the 0.01 level (2-tailed).

a. Daya 900 VA

Model Summary

\begin{tabular}{|l|r|r|r|r|}
\hline Model & \multicolumn{1}{|l|}{$\mathrm{R}$} & R Square & $\begin{array}{r}\text { Adjusted } \\
\text { R Square }\end{array}$ & $\begin{array}{r}\text { Std. Error of } \\
\text { the Estimate }\end{array}$ \\
\hline 1 &, $571^{\mathrm{a}}$ &, 326 &, 289 & 14,900 \\
\hline
\end{tabular}

a. Predictors: (Constant), UmurInstalasi 
ISSN 1979-7540

Correlations

\begin{tabular}{|ll|r|r|}
\hline & & Arusbocor & UmurInstalasi \\
\hline Arusbocor & Pearson Correlation & 1 &, 571 ** \\
& Sig. (2-tailed) & &, 009 \\
& $\mathrm{~N}$ & 20 & 20 \\
\hline UmurInstalasi & Pearson Correlation &, $571 * *$ & 1 \\
& Sig. (2-tailed) &, 009 & 20 \\
\hline & N & 20 & 20 \\
\hline
\end{tabular}

\section{b. Daya 1300 VA}

Tabel. 3. Hasil Analisis Korelasi Data
a.Daya $900 \mathrm{VA}$
b.Daya $1300 \mathrm{Va}$

Angka korelasi berkisar antara 0 dan 1 , sehingga untuk mudahnya hubungan antara dua variabel dikatakan kuat jika lebih dari 0,5 dan dianggap lemah jika kurang dari 0,5. Dari data yang diperoleh pata tabel 5.2. terlihat hubungan yang cukup kuat antara umur instalasi dengan arus bocor yaitu sebesar 0,535 (900 A) dan 0,571 ( $1300 \mathrm{VA}$ ), dengan tingkat signifikansi yang sangat baik yaitu 0,002 ( 900 VA ) dan 0,009 ( 1300 VA ) semua lebih kecil dai batas signifikansi yang ditetapkan yaitu 0,01 . Ini menunjukkan besarnya arus bocor yang terjadi sangat dipengaruhi berapa lama umur instalasi rumah tangga tersebut, semakin lama umur instalasi sebuah rumah tangga maka akan semakin besar pula arus bocornya.

Nilai $\mathrm{R}^{2}$ adalah koefisien determinasi, yang menjelaskan tentang hubungan antara variable independen dengan variabel dependen atau melihat kecocokan model terhadap kondisi alamiahnya. Angka $\mathrm{R}^{2}$ dalam penelitian ini adalah 0,287 atau 28,7 $\%$ untuk daya 900 VA dan 0,326 atau 32,6\% untuk daya 1300 VA. Ini menunjukkan bahwa variabel umur instalasi hanya mempengaruhi variabel arus bocor sebesar $28,7 \%$ dan $32,6 \%$ sehingga masih ada sebesar 72,3\% dan 68,4\% dijelaskan oleh sebab-sebab yang lain yang tidak diamati dalam model ini.

\section{Arus Bocor dan Daya Terpasang}

\begin{tabular}{|c|c|c|c|c|}
\hline \multicolumn{5}{|c|}{ Correlations } \\
\hline & & Arusbocol & UmurInstalas & Daya \\
\hline \multirow[t]{3}{*}{ Arusbocor } & Pearson Correlation & 1 &, $534^{*}$ & ,254 \\
\hline & Sig. (2-tailed) & & ,000 & ,075 \\
\hline & $\mathrm{N}$ & 50 & 50 & 50 \\
\hline \multirow[t]{3}{*}{ UmurInstalasi } & Pearson Correlation &, $534 *$ & 1 & ,015 \\
\hline & Sig. (2-tailed) & ,000 & & ,917 \\
\hline & $\mathrm{N}$ & 50 & 50 & 50 \\
\hline \multirow[t]{3}{*}{ Daya } & Pearson Correlation &, 254 & ,015 & 1 \\
\hline & Sig. (2-tailed) & 075 & ,917 & \\
\hline & $\mathrm{N}$ & 50 & 50 & 50 \\
\hline
\end{tabular}

Tabel. 4. Hasil Analisis Korelasi Data Daya dan Arus Bocor

Dari data yang diperoleh pata tabel 5.3. terlihat hubungan yang tidak cukup kuat antara arus bocor dengan daya terpasang yaitu sebesar 0,254, dengan tingkat signifikansi yang sangat baik yaitu 0,075 . Ini menunjukkan besarnya arus bocor yang terjadi juga dipengaruhi berapa besar daya terpasang diinstalasi rumah tangga tersebut, semakin besar daya terpasang maka akan semakin besar pula arus bocornya, namun pengaruh daya terpasang terhadap terjadinya arus bocor tidak cukup kuat.

\section{B. Hasil Analisis Regresi}

Hasil Analisis regresi dapat dilihat pada tabel berikut ini :

\section{Regression}

Variables Entered/Removed b

\begin{tabular}{|l|l|l|l|}
\hline Model & $\begin{array}{l}\text { Variables } \\
\text { Entered }\end{array}$ & $\begin{array}{c}\text { Variables } \\
\text { Removed }\end{array}$ & Method \\
\hline 1 & $\begin{array}{l}\text { Daya, } \\
\text { Umur } \\
\text { Instalasi a }\end{array}$ & & Enter \\
\hline
\end{tabular}

a. All requested variables entered.

b. Dependent Variable: Arusbocor

a. Validasi Data yang diolah 
Model Summary

\begin{tabular}{|l|r|r|r|r|}
\hline Model & \multicolumn{1}{|l|}{$\mathrm{R}$} & R Square & $\begin{array}{r}\text { Adjusted } \\
\text { R Square }\end{array}$ & $\begin{array}{r}\text { Std. Error of } \\
\text { the Estimate }\end{array}$ \\
\hline 1 &, $588 \mathrm{a}$ &, 345 &, 317 & 15,688 \\
\hline
\end{tabular}

a. Predictors: (Constant), Daya, UmurInstalasi

b. Model Summary

ANOVA b

\begin{tabular}{|c|c|c|c|c|c|c|}
\hline \multicolumn{2}{|c|}{ Model } & $\begin{array}{c}\text { Sum of } \\
\text { Squares }\end{array}$ & $\mathrm{df}$ & Mean Squar & $\mathrm{F}$ & Sig. \\
\hline \multirow[t]{3}{*}{1} & Regression & 6102,33 & 2 & 3051,16 & 12,397 &, 000 \\
\hline & Residual & 11567,66 & 47 & 246,121 & & \\
\hline & Total & 17670,00 & 49 & & & \\
\hline
\end{tabular}

a. Predictors: (Constant), Daya, UmurInstalasi

b. Dependent Variable: Arusbocor

\section{c. Hasil Uji Anova}

Coefficients

\begin{tabular}{|c|c|c|c|c|c|c|}
\hline \multirow{2}{*}{\multicolumn{2}{|c|}{ Model }} & \multicolumn{2}{|c|}{$\begin{array}{l}\text { Unstandardized } \\
\text { Coefficients }\end{array}$} & \multirow{2}{*}{$\begin{array}{c}\text { Standardize } \\
\text { Coefficient } \\
\text { Beta }\end{array}$} & \multirow[b]{2}{*}{$\mathrm{t}$} & \multirow[b]{2}{*}{ Sig. } \\
\hline & & B & Std. Erro & & & \\
\hline \multirow[t]{3}{*}{1} & (Constant) & $-30,339$ & 15,978 & & $-1,899$ &, 064 \\
\hline & UmurInstalasi & 3,710 &, 826 &, 530 & 4,490 &, 000 \\
\hline & Daya &, 024 &, 011 & 246 & 2,084 & 043 \\
\hline
\end{tabular}

a. Dependent Variable: Arusbocor

\section{d. Kofisien Regresi}

Tabel. 5. Hasil Analisis Regresi Data

Model dengan dua variabel bebas, adalah sebagai berikut:

$y=-30,339+3,710 X_{1}+0,24 X_{2}$

Model dengan dua variabel bebas diatas memberikan pengaruh sebesar 34,51\% terhadap arus bocor yang terjadi.

Dari model ini terlihat untuk daya terpasang yang tetap maka kenaikan umur isatalasi sebesar satu satuan akan menyebabkan kenaikan arus bocor sebesar
3,71 kali . sementara untuk umur instalasi yang sama maka kenaikan daya terpasang satu satuan akan menyebabkan kenaikan arus bocor hanya sebesar 0,24 kali.

Data arus bocor pada penelitian ini tersebar. Peningkatan nilai pengaruh umur terhadap arus bocor nampak dengan meningkatnya nilai korelasi serta turunnya nilai signifikansi seperti yang ag terlihat pada table 5.2. diatas . Pengaruh umur pada instalasi listrik 1300 VA adalah 32,6 \%, pada instalasi listrik 900 VA di bawah $28,7 \%$

Pengaruh umur instalasi listrik terhadap arus bocor lebih kecil daripada pengaruh daya terpasang pada table 5.3.

Sementara factor kerusakan dapat diaumsikan cukup kecil ini dapat disebabkan oleh keunggulan sifat isolasi jenis PVC yaitu mempunyai umur yang sangat panjang selain mempunyai ketahanan terhadap berbagai bahan kimia. (Van Harten, 1991)

Daya terpasang yang menunjukkan besar arus maksimal yang bisa dimanfaatkan oleh instalasi mencerminkan jumlah beban yang lebih besar maupun saluran yang lebih panjang dibutuhkan untuk semuah instalasi dengan daya terpasang yang lebih besar oleh karena itu maka variabel yang dimungkinkan berpengaruh terhadap arus bocor pada daya terpasang adalah adalah panjang saluran akibat besarnya daya tersebut.

\section{Pengaruh Arus Bocor terhadap Pembayaran Rekening}

Arus bocor instalasi listrik rumah tangga merugikan konsumen, yang perbulannya dapat dihitung sebagai berikut :

Biaya $/$ bulan $=($ biaya/jam $) \times 24$ jam $\times 30$ hari

$$
\begin{aligned}
\text { Biaya } / \text { jam } & =k W h \times \text { tarif } \\
W h & =V \times \text { i...(6) } \\
& =\text { jam }
\end{aligned}
$$

dengan :

$$
\begin{aligned}
\mathrm{Wh} & =\mathrm{VA} \text { hour (VA jam) } \\
\mathrm{kWh} & =1000 \mathrm{Wh} \\
\mathrm{V} & =\text { Tegangan (Volt) } \\
\mathrm{I} & =\text { Arus (Ampere) }
\end{aligned}
$$


Tarif = Tarif listrik (tergantung pada TDL)

Dari data yang ada dengan rata rata data arus bocor untuk daya $900 \mathrm{VA}$ sebesar $37,9 \mathrm{~mA}$ maka rata rata kerugian konsumen dapat dihitung sebagai berikut :

$$
\begin{aligned}
\mathrm{Wh} & =\mathrm{V} \times \mathrm{i} \times 1 \mathrm{jam} \\
& =220 \times 0,0379 \times 1 \\
& =8,338 \mathrm{VA} \mathrm{jam} \\
& =8,338 \times 10^{-3} \mathrm{kWh}
\end{aligned}
$$

Biaya perjamnya untk asumsi pemakaian diatas $60 \mathrm{kWh}$ adalah

$$
\begin{aligned}
\text { Biaya } / \text { jam } & \\
= & \mathrm{kWh} \times \text { tarif } \\
= & 8,338 \times 10^{-3} \times 360 \\
= & 3001,68 \times 10^{-3} \\
= & \text { Rp. } 3,00168,- \\
= & \text { (biaya/jam) } \mathrm{j} 24 \\
& \text { jam } \times 30 \\
= & 3,00168 \times 24 \times 30 \\
= & \text { Rp. } 2.161,1,-
\end{aligned}
$$

Penambahan biaya perbulan rata rata dari sampel yang ada selama setahun untuk daya terpasang 900 VA Rp. 2.161,1 ,-

Dari data yang ada dengan rata rata data arus bocor untuk daya 1300 VA sebesar 47,95 $\mathrm{mA}$ maka rata rata kerugian konsumen dapat dihitung sebagai berikut :

$$
\begin{aligned}
\mathrm{Wh} & =\mathrm{V} \times \mathrm{i} \times 1 \mathrm{jam} \\
& =220 \times 0,04795 \mathrm{x} 1 \\
& =10,549 \mathrm{VA} \mathrm{jam} \\
& =10,549 \times 10^{-3} \mathrm{kWh}
\end{aligned}
$$

Biaya perjamnya untuk asumsi pemakaian diatas $60 \mathrm{kWh}$ adalah

$$
\begin{aligned}
\text { Biaya } / \text { jam } & =\mathrm{kWh} \times \text { tarif } \\
= & 10,549 \times 10^{-3} \times 405 \\
= & 4272,345 \times 10^{-3} \\
= & \text { Rp. } 4.272,345,- \\
\text { Biaya / bulan } & =(\text { biaya/jam) } \times 24 \\
& \text { jam } \times 30 \\
= & 4.272,345 \times 24 \times 30 \\
= & \text { Rp. } 3.076,,-
\end{aligned}
$$

Penambahan biaya perbulan rata rata dari sampel yang ada selama setahun untuk daya terpasang 900 VA Rp. 3.076,-
Selanjutnya dapat diperlihatkan oleh Grafik berikut :

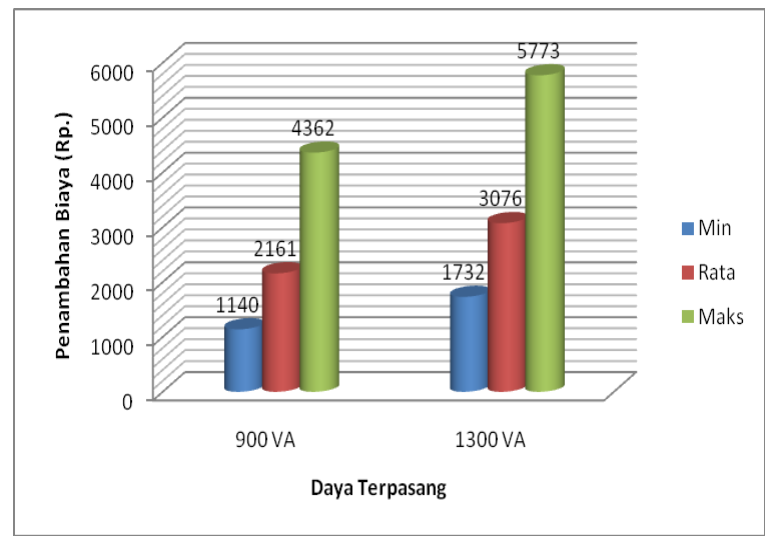

Gambar. 2. Grafik Perbandingan Penambahan Biaya akibat arus bocor dengan daya terpasang

Dari gambar tampak bahwa penambahan biaya perbulan tidak cukup besar dengan penambahan maksimum sebesar Rp. 5.773 ,untuk daya 1300 VA sedngkan untuk Daya 900 VA sebesar Rp. 4.362,-

\section{KESIMPULAN}

1. Arus bocor terjadi pada seluruh Instalasi rumah tangga yang diteliti dengan besar arus bocor bervariasi antara $20-90 \mathrm{~mA}$, dan rata rata 37,9 mA untuk Daya terpasang 900 VA dan bervariasi antara 27 - $90 \mathrm{~mA}$ dan rata rata $47,95 \mathrm{~mA}$ untuk daya terpasang 1300 VA, nilai ini masih dibawah batas wajar yaitu $300 \mathrm{~mA}$.

2. Besar arus bocor dipengaruhi oleh umur instalasi dan besar daya terpasang, umur Instalasi mempengaruhi sebesar $28,7 \%$ untuk daya 900 VA dan $32,6 \%$ untuk daya $1300 \mathrm{VA}$, sementara pengaruh daya terpasang relatif cukup kecil.

3. Besarnya arus bocor rata rata menyebabkan perbedaan pembayaran sebesar Rp.1140 - Rp 4.326 untuk daya 900 VA dengan rata rata Rp. 2161,- . sedangkan untuk daya 1300 VA sebesar Rp. 1.732 - Rp. 5.773 ,- dengan rata rata Rp. 3.076,- 
4. Faktor lain yang memungkinkan penyebab perbedaan adalah pengaruh arus bocor yang dihubungkan dengan panjang saluran pada instalasi rumah tangga.

\section{DAFTAR PUSTAKA}

1. Arismunandar, A., 1994, Teknik Tegangan Tinggi, Pradnya Paramita, Jakarta.

2. Dajan, A,. 1978. Pengantar Metode Statistik Jilid II, LP3ES, Jakarta.

3. Haryono, T., Kusumawardani, S.K., Hidayat, I., Analisis Kualitas Instalasi Listrik Rumah Tangga., Proceedings SNTK 2007, Unhas, Makassar

4. Malik, N.H., Al Arrainy, A.A., Qureshi, M.I., 1998. Electrical Insulation in Power System, Marcell Dekker Inc, New York.

5. Naidu M.S.., Kamaraju, V., 1995. High Voltage Engeneering . Tata McGrawHill Co., New Delhi .

6. Sembiring , R.K., 1995. Analisis Regresi, Penerbit ITB, Bandung.

7. Van Harten, P., 1991. Instalasi Listrik Arus Kuat I, Binacipta, Bandung. 